\title{
A Radioresistant Gram-positive Asporogenous Rod Isolated from the Faeces of a Giant Panda (Ailuropoda melanoleuca)
}

\author{
By MICHIKO KOBATAKE AND H. KURATA \\ Department of Microbiology, National Institute of Hygienic Sciences, Setagaya-ku, \\ Tokyo 158, Japan \\ AND K. KOMAGATA \\ Institute of Applied Microbiology, University of Tokyo, \\ Bunkyo-ku, Tokyo I I3, Japan
}

(Received 7 September 1976; revised 10 December 1976)

SUMMAR Y

\begin{abstract}
A highly radioresistant bacterium was isolated from the faeces of a giant panda (Ailuropoda melanoleuca). When the organism was subjected to gamma irradiation in phosphate buffer, the induction dose and $\mathrm{D}_{10}$ values were 846 and $345 \mathrm{krad}$, respectively, for cells grown on PCNZ agar, and 700 and 460 krad, respectively, for the enlarged cells grown on $5 \%(\mathrm{v} / \mathrm{v})$ horse blood brain heart infusion agar. The $\mathrm{D}_{10}$ value of the former cells was about I 8 times higher than that of Micrococcus radiodurans grown on PCNZ agar.
\end{abstract}

\section{INTRODUCTION}

Several bacteria which are highly resistant to gamma rays have been reported (Davis, Silverman, \& Masurovsky, I963; Ito \& Iizuka, 197I; Lewis, I97I ; Yoshinaka, Yano \& Yamaguchi, 1973; Matsuyama et al., 1973; Yano et al., 1975; Welch \& Maxcy, 1975) since the radioresistant bacterium Micrococcus radiodurans was first isolated from irradiated meat (Anderson et al., I956). Kobatake, Tanabe \& Hasegawa (1973) reported radioresistant bacteria in the faeces of 30 kinds of animals, and isolated Micrococcus radioproteolyticus from the faeces of a llama (Lama glama). We report here the properties of a highly radioresistant Gram-positive asporogenous bacterium isolated from the faeces of the giant panda (Ailuropoda melanoleuca).

\section{METHODS}

Media. Three isolation media were used: nutrient agar (Difco); brain heart infusion (BHI) agar (Difco); and PCNZ agar (Krabbenhoft, Anderson \& Elliker, I967), which contained $\left(\mathrm{g} \mathrm{l}^{-1}\right)$ : tryptone, $5^{\circ} \mathrm{O}$; yeast extract, 2.5 ; glucose, I.0; NZ-case (Sheffield Chemical Co., Norwich, New York, U.S.A.), 5•0; agar, I5.0; pH 7.0.

Isolation of organisms. Faeces samples were collected from a healthy 4 -year-old female and a 3-year-old male giant panda; they contained undigested bamboo leaves, sugar cane, jujube, chopped straw and mucus. Samples ( $1 \mathrm{ml}$ ) of dilutions of the faeces were spread on each of the plating media in stainless-steel trays $(220 \times 280 \times 35 \mathrm{~mm})$, and incubated at $37^{\circ} \mathrm{C}$ for I week. Pure cultures were obtained by repeated subculture on PCNZ agar, and maintained on PCNZ agar slants. All strains were cultivated at $37^{\circ} \mathrm{C}$ unless stated otherwise. 
Identification methods. Morphological characters were recorded for strains grown on four different media: PCNZ agar; nutrient agar (Difco); $5 \%(\mathrm{v} / \mathrm{v})$ horse blood BHI agar; and EYGA medium (Cure \& Keddie, 1973), which contained (per 1 mineral base E): yeast extract, I g; glucose, I g; purified agar, $12 \mathrm{~g}$; and vitamin $\mathrm{B}_{12}, 2 \mu \mathrm{g}$. Morphological changes during the growth cycle were examined in microcultures on EYGA medium, incubated at $25^{\circ} \mathrm{C}$, by the method of Komagata, Yamada \& Ogawa (1969). Biochemical and physiological characters were tested as described by Yamada \& Komagata (1972) and Cowan \& Steel (1974), and vitamin requirements were examined by the method of Keddie, Leask \& Grainger (I966). The principal amino acids in the cell walls and the GC content of the DNA were determined as described by Yamada \& Komagata (I970a, b), and menaquinones isolated from lyophilized organisms were identified by paper chromatography and mass spectrometry (Yamada et al., 1976).

For the toxicity test, $48 \mathrm{~h}$ cultures in BHI broth were centrifuged and I $\mathrm{ml}$ of the packed cells and $\mathrm{I} \mathrm{ml}$ of the supernatant fluid were injected intravenously into each of five mice. Mean generation times were determined from growth curves by measuring the extinction of PCNZ broth cultures shaken in a Monod type L-tube.

Irradiation. Forty-six faecal isolates were screened for high radioresistance. 'Test pieces' for gamma irradiation (discs of dried bacteria), prepared by the method of Christensen \& Holm (1964) as modified by Tanabe et al. (197I), were irradiated with doses ranging from 0.1 to $6.0 \mathrm{Mrad}$ in rubber-stoppered test tubes $(20 \times \mathrm{I} 80 \mathrm{~mm})$ containing about $5 \mathrm{~g}$ silica gel. Irradiation was carried out at a dose rate of $16.4 \mathrm{krad} \mathrm{min}^{-1}$ at room temp. (about $18{ }^{\circ} \mathrm{C}$ ) in a ${ }^{60} \mathrm{Co}$ plant (Institute of Physical and Chemical Research, Wako-shi, Saitama, Japan). Irradiated bacteria were suspended in 0.067 M-phosphate buffer $\mathrm{pH} 7.0$ and serially diluted. Colony counts were made on PCNZ agar plates after 5 days incubation.

Strain P-30-A (the most radioresistant strain isolated), strain P-30-B (an orange-coloured mutant derived from strain P-30-A by a gamma radiation dose of $\mathrm{I} \cdot 3 \mathrm{Mrad}$ ) and $M$. radiodurans $\mathrm{R}_{1}$ (Duggan, Anderson \& Elliker, 1963), which was kindly supplied by Dr Matsuyama, were irradiated in phosphate buffer to compare their radiosensitivities. The radiosensitivities of strain P-30-A grown under the same conditions on two different media were also compared since the shapes and sizes of these bacteria varied with the growth environment. Thus four types of cells were studied: single or paired cells of strain P-3-OA grown on PCNZ agar (PCNZ-A cells); single or paired cells of strain P-30-B grown on PCNZ agar (PCNZ-B cells); enlarged and chained cells of strain P-30-A grown on the blood BHI agar (BHI-A cells); and cells of $M$. radiodurans $\mathrm{R}_{1}$ grown on $\mathrm{PCNZ}$ agar ( $\mathrm{PCNZ}-\mathrm{R}_{1}$ cells). The test strains, freshly subcultured on to PCNZ agar slants, were inoculated heavily on to PCNZ agar or blood BHI agar plates and incubated for $48 \mathrm{~h}$. Phosphate buffer suspensions were then prepared to give a concentration of approximately $10^{8}$ cells $\mathrm{ml}^{-1}$. BHI-A cells were carefully suspended to avoid damaging the chains. Test tubes containing $5 \mathrm{ml}$ of the prepared suspensions were irradiated, with air equilibrium, at room temperature as before.

\section{RESULTS}

\section{Isolation of organism}

The number of aerobic bacteria found in the faeces of the two giant pandas was in the range $1 \mathrm{O}^{7}$ to $1 \mathrm{O}^{9}$ ( $\mathrm{g}$ wet $\left.\mathrm{wt}\right)^{-1}$; the highest counts were obtained on $\mathrm{PCNZ}$ and blood $\mathrm{BHI}$ agar plates. Of the 46 bacterial strains isolated, which represented various colony types, 40 were relatively sensitive to gamma radiation (A, Fig. 1), whereas five strains, identified as Bacillus cereus, B. subtilis, Micrococcus sp., Streptococcus sp. and a coryneform bacterium, 


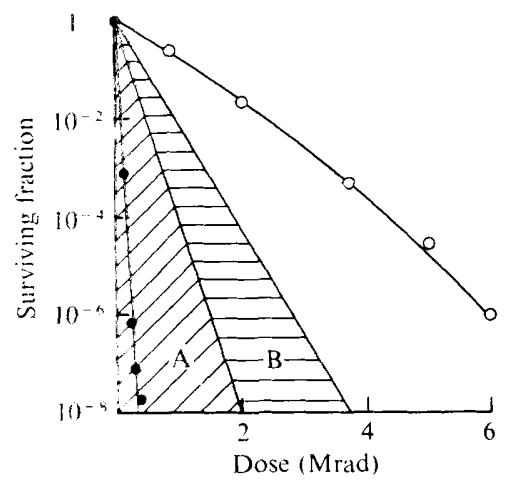

Fig. I

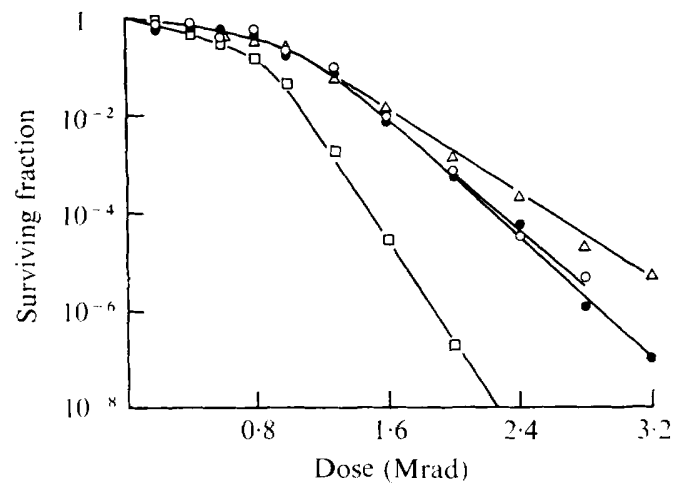

Fig. 2

Fig. 1. Survival curves for bacteria isolated from the faeces of the giant panda: area A, 40 unidentified strains; area B, Bacillus cereus, B. subtilis, Micrococcus sp., Streptococcus sp. and a coryneform $\mathrm{P}-2 ; \mathrm{C}$, strain P-30-A. Cells grown on PCNZ agar were gamma-irradiated under dry conditions. The survival curve of Corynebacterium equi IAMIO38 (O) is included for comparison.

Fig. 2. Survival curves of strain P-30-A grown on PCNZ agar $(\bigcirc)$, strain P-30-B grown on PCNZ agar (๑), strain P-30-A grown on blood BHI agar $(\triangle)$, and $M$. radiodurans $\mathrm{R}_{1}$ grown on $\mathrm{PCNZ}$ agar $(\square)$. Cells grown at $37^{\circ} \mathrm{C}$ for $48 \mathrm{~h}$ were gamma-irradiated in $0.067 \mathrm{M}$-phosphate buffer solution.

required doses of 2.0 to $3.7 \mathrm{Mrad}$ to achieve an inactivation factor of $10^{8}$ (B, Fig. I). Strain P-30-A was the most radioresistant of the isolates; it was not exposed to gamma radiation in the course of its isolation.

\section{Characteristics of strain $\mathrm{P}-30-\mathrm{A}$}

Strain P-30-A was Gram-positive, aerobic, non-sporeforming, non-motile and produced rods which contained metachromatic granules. Coccoid cells, inoculated on to EYGA medium, elongated into rods forming a transverse septum by which fission took place. After 6 to 7 days coccoid cells appeared.

On PCNZ and nutrient agars, rods with rounded or tapered ends $(0.7$ to $0.9 \times 0.9$ to $3.0 \mu \mathrm{m}$ ) occurred singly, in pairs or, rarely, as short chains when cultured for $6 \mathrm{~h}$ to I week; a few slightly curved, long filaments $(0.8$ to $\mathrm{I} \cdot 0 \times 40$ to $60 \mu \mathrm{m})$ or long cells were also found.

On blood BHI agar, slightly curved or V-shaped rods $(0.8$ to $\mathrm{I} .0 \times \mathrm{I} \cdot 2$ to $3.0 \mu \mathrm{m})$ were present after 6 to $8 \mathrm{~h}$. After $24 \mathrm{~h}$, chains and ghost-like spherical cells ( $\mathrm{I} \cdot 0$ to $5^{\circ} \mu \mu \mathrm{m}$ diam.) formed. By $48 \mathrm{~h}$ the chains were 20 to $30 \mu \mathrm{m}$ long and consisted of about 15 cells $(\mathrm{I} \cdot 5$ to $2.5 \times \mathrm{I} \cdot 5$ to $3 \cdot 0 \mu \mathrm{m})$. Short chains, paired rods and swollen cells were also found. After 7 days large, long, translucent cells ( $\mathrm{I} \cdot \mathrm{O}$ to $2.5 \times 10$ to $70 \mu \mathrm{m}$ ) containing small or large Grampositive granules appeared.

On nutrient agar, circular, raised, smooth, entire, glistening, opaque, cream to pale flesh-coloured colonies were formed, and nutrient broth cultures were slightly turbid with little sediment.

The organism did not produce indole or $\mathrm{H}_{2} \mathrm{~S}$, was methyl red and Voges-Proskauer negative, did not degrade cellulose or aesculin or change litmus milk, and did not produce acid from ribose, L-arabinose, xylose, rhamnose, glucose, fructose, mannose, galactose, sucrose, lactose, maltose, starch, glycerol, mannitol, sorbitol or inositol. Ammonia was not produced from arginine; oxidase and catalase were present; urease, lecithinase and tyrosinase were absent; an extracellular DNAase was detected; gelatin and starch were degraded; and nitrate was reduced to nitrite. Acetate, pyruvate, lactate, $\alpha$-ketoglutarate, formate and 
Table I. Radiosensitivity of the bacteria isolated from the faeces of the giant panda under dry conditions

\begin{tabular}{|c|c|c|c|}
\hline \multirow[b]{2}{*}{ Organism } & \multicolumn{3}{|c|}{ Surviving fraction } \\
\hline & $0.3 \mathrm{Mrad}$ & I.o Mrad & 2.0 Mrad \\
\hline Strain P-30-A & $5.9 \times 10^{-1}$ & $\mathrm{I} \cdot 8 \times \mathrm{IO}^{-1}$ & $2.6 \times 10^{-2}$ \\
\hline Micrococcus sp. P-3 & $5.0 \times 10^{-2}$ & $8.9 \times 10^{-5}$ & - \\
\hline Streptococcus sp. P-43 & $8 \cdot 3 \times 10^{-2}$ & $2.6 \times 10^{-4}$ & $1.0 \times 10^{-7}$ \\
\hline Bacillus cereus $\mathrm{P}-32$ & $\mathrm{I} \cdot 8 \times \mathrm{IO}^{-1}$ & $5.3 \times 10^{-3}$ & $3.5 \times 10^{-5}$ \\
\hline B. subtilis $\mathrm{P}-\mathrm{IO}$ & $2.0 \times 10^{-1}$ & $6.7 \times 10^{-3}$ & $5.1 \times 10^{-5}$ \\
\hline Coryneform P-2 & $1.2 \times 10^{-1}$ & $I \cdot I \times 10^{-3}$ & $1.6 \times 10^{-6}$ \\
\hline 40 unidentified bacteria & $<5^{\circ} \mathrm{O} \times \mathrm{IO}^{-2}$ & $<8.9 \times 10^{-5}$ & - \\
\hline Corynebacterium equi IAMI038 & $1 \cdot 3 \times 10^{-7}$ & - & - \\
\hline
\end{tabular}

Table 2. Radiosensitivity of strain P-30-A grown on two different media, of its orange-coloured mutant $\mathrm{P}-3 \mathrm{O}-\mathrm{B}$ and of Micrococcus radiodurans $\mathrm{R}_{\mathbf{1}}$

\begin{tabular}{|c|c|c|c|c|c|}
\hline Organism & $\begin{array}{c}\text { Induction } \\
\text { dose } \\
\text { (krad) }\end{array}$ & $\begin{array}{c}D_{10} \\
\text { value } \\
\text { (krad) }\end{array}$ & $\begin{array}{l}\text { Culture } \\
\text { medium }\end{array}$ & Shape of cells at $48 \mathrm{~h}$ & $\begin{array}{l}\text { Pigmentation } \\
\text { of colony }\end{array}$ \\
\hline Strain $\mathrm{P}-30-\mathrm{A}$ & 846 & 345 & PCNZ & Single or paired rods & Cream to pale flesh \\
\hline Strain $\mathrm{P}-30-\mathrm{B}$ & 855 & 334 & PCNZ & Single or paired rods & Orange \\
\hline Strain P-30-A & 700 & 460 & Blood BHI & Enlarged and chained rods & Greyish-cream \\
\hline$M$. radiodurans $\mathrm{R}_{1}$ & 727 & 195 & PCNZ & Single or tetrad cocci & Brownish-red \\
\hline
\end{tabular}

hippurate were utilized as sole sources of carbon for energy and growth but malate, succinate, fumarate, citrate, propionate, oxalate, gluconate and urate were not.

Neither the culture broth, not its supernatant fluid after centrifuging, was fatal to mice.

No growth occurred in $5 \%(\mathrm{w} / \mathrm{v}) \mathrm{NaCl}$ broth or in a mineral salts plus glucose medium unless vitamin-free Casamino acids (Difco) were added. The optimum temperature for growth was $37^{\circ} \mathrm{C}$; no growth occurred at $40^{\circ} \mathrm{C}$ or below $10{ }^{\circ} \mathrm{C}$. The organism was not resistant to heating at $63^{\circ} \mathrm{C}$ for 30 min in skim milk. Its optimum $\mathrm{pH}$ was between 7.0 and 7.4 .

The organism had a GC content of $65.7 \mathrm{~mol} \%$, contained lysine as the principal cellwall amino acid, and possessed menaquinones with eight isoprene units (MK-8).

The organism cannot be classified with confidence at present, and has been deposited at the Institute of Applied Microbiology, University of Tokyo, Japan; accession number IAMI 2120.

The morphological, biochemical and physiological characteristics of strain P-30-B (IAMI 2 I 40) are similar to those of strain P-30-A.

\section{Radiosensitivities}

Under dry conditions, the radiation resistance of strain P-3O-A was considerably higher than the resistance of Corynebacterium equi IAMIO 38 and of a coryneform bacterium isolated from the faeces of a female giant panda (Fig. I, Table I). The shape of the survival curve of strain P-30-A resembled that of the coryneform bacteria illustrated by Christensen, Holm \& Juul (1967).

In phosphate buffer strains P-30-A and P-30-B exhibited sigmoidal survival curves which were similar to that of $M$. radiodurans $\mathrm{R}_{\mathbf{1}}$ (Fig. 2). However, $\mathrm{D}_{10}$ values on the exponential part of the survival curves for the two test strains were higher than that for $M$. radiodurans $\mathbf{R}_{\mathbf{1}}$. 
$\mathrm{D}_{10}$ values of PCNZ-A and BHI-A cells were, respectively, about 1.8 and 2.4 times higher than that of PCNZ- $\mathrm{R}_{1}$ cells. There was no correlation between pigmentation and radiation resistance (Fig. 2, Table 2) as investigated by Okazawa \& Matsuyama (1967), and Suhadi et al. (1972).

\section{DISCUSSION}

Strains $\mathrm{P}-3 \mathrm{O}-\mathrm{A}$ and $M$. radiodurans $\mathrm{R}_{\mathbf{1}}$ showed approximately the same induction dose. Hence, if radiation induced similar lesions in their DNAs, their primary repair mechanisms must be qualitatively similar. However, there were large differences between the $D_{10}$ values on the exponential part of the survival curves for these two bacteria. Kitayama $\&$ Matsuyama (1970) suggested that in $M$. radiodurans damage to cytoplasmic components, such as the system for protein synthesis, would become a critical factor in the survival of organisms subjected to high doses of irradiation. If this were so with strain P-30-A, then it is unlikely that the system for protein synthesis, which might be required for the completion of DNA repair, is damaged, otherwise the ability of strain P-30-A to recover from radiation damage would have to be greater than that of $M$. radiodurans.

There is little difference between the $\mathrm{D}_{10}$ values of PCNZ-A and BHI-A cells. In Escherichia coli the radiosensitivity of cells is affected by the composition of the culture medium and by the phase of the growth cycle (Stapleton \& Fisher, 1967; Town, Smith \& Kaplan, 1970). The difference in $\mathrm{D}_{10}$ values between PCNZ-A and BHI-A cells could, therefore, be due to differences in DNA repair ability or protein synthesis activity which reflect the different growth media.

Strain P-30-A not only shows considerable radiation resistance but also has a short mean generation time $(60 \mathrm{~min})$, and it is not difficult to extract DNA from the organism. This bacterium might, therefore, be suitable for investigations into the mechanism of extreme radiation resistance in bacteria.

This study was supported by a grant from the Science and Technology Agency of Japan. The authors are indebted to Drs S. Tanabe, A. Matsuyama, Y. Okazawa, K. Yano, K. Yamada, Y. Yamada and Mr K. Nakano for help and valuable suggestions, and wish to express their appreciation to Drs K. Tashiro and S. Nakagawa for the supply of faecal samples, and to Mrs M. Fujiwara and Miss K. Ando for technical assistance.

\section{REFERENCES}

Anderson, A. W., Nordan, H. C., Cain, R. F., Parrish, G. \& Duggan, D. (1956). Studies on the radioresistant Micrococcus. I. Isolation, morphology, cultural characteristics, and resistance to gamma radiation. Food Technology ro, 575-577.

Christensen, E. A. \& Holm, N. W. (I964). Inactivation of dried bacteria and bacterial spores by means of ionizing radiation. Acta pathologica et microbiologica scandinavica 6o, 253-264.

Christensen, E. A., Holm, N. W. \& JuUl, F. A. (1967). Radiosterilization of medical devices and supplies. In Radiosterilization of Medical Products, IAEA-SM-92/22, pp. 265-283. Vienna: International Atomic Energy Agency.

CowAN, S. T. \& STEEL, K. J. (1974). Manual for the Identification of Medical Bacteria, 2nd edn. Cambridge: Cambridge University Press.

Cure, G. L. \& Keddie, R. M. (1973). Methods for the morphological examination of aerobic coryneform bacteria. In Sampling-Microbiological Monitoring of Environments, pp. 123-135. Edited by R. G. Board and D. W. Lovelock. London and New York: Academic Press.

Davis, N. S., Silverman, G. J. \& Masurovsky, E. B. (I963). Radiation-resistant, pigmented coccus isolated from haddock tissue. Journal of Bacteriology 86, 294-298.

Duggan, D. E., Anderson, A. W. \& Elliker, P. R. (I963). Inactivation of the radiation-resistant spoilage bacterium Micrococcus radiodurans. I. Radiation inactivation rates in three meat substrates and in buffer. Applied Microbiology II, 398-403. 
Ito, H. \& Irzuka, H. (I97I). Taxonomic studies on a radio-resistant Pseudomonas. Studies on the microorganisms of cereal grain. Part XII. Agricultural and Biological Chemistry 35, 1566-1 57 I.

Keddie, R. M., Leask, B. G. S. \& Grainger, J. M. (I966). A comparison of coryneform bacteria from soil and herbage: cell wall composition and nutrition. Journal of Applied Bacteriology 29, 17-43.

Kitayama, S. \& Matsuyama, A. (1970). Macromolecular synthesis in Micrococcus radiodurans during post-irradiation incubation. Agricultural and Biological Chemistry 34, I095-1 100.

Kobatake, M., Tanabe, S. \& Hasegawa, S. (1973). Nouveau micrococcus radioresistant à pigment rouge, isolé de fèces de Lama glama, et son utilisation comme indicateur microbiologique de la radiostérilisation. Comptes rendus des séances de la Société de biologie 167, I 506-1510.

Komagata, K., Yamada, K. \& Ogawa, H. (I969). Taxonomic studies on coryneform bacteria. 1. Division of bacterial cells. Journal of General and Applied Microbiology 15, 243-259.

Krabbenhoft, K. L., Anderson, A. W. \& Elliker, P. R. (I967). Influence of culture media on the radiation resistance of Micrococcus radiodurans. Applied Microbiology 15, I78-185.

LEWIS, N. F. (197I). Studies on a radio-resistant coccus isolated from Bombay duck (Harpodon nehereus). Journal of General Microbiology 66, 29-35.

Matsuyama, A., Okazawa, Y., Arai, H. \& Mrfune, M. (1973). Isolation of radioresistant vegetative bacteria from the high-background radioactive area. Scientific Papers of the Institute of Physical and Chemical Research 67, 35-40.

Okazawa, Y. \& Matsuyama, A. (I967). A note on radiation resistance of Micrococcus radiodurans. Agricultural and Biological Chemistry 31, I505-1508.

Stapleton, G. E. \& Fisher, W. E. (I967). Macromolecular synthesis and radiosensitivity in Escherichia coli. Radiation Research 30, I73-I85.

Suhadi, F., Kitayama, S., Okazawa, Y. \& Matsuyama, A. (1972). Isolation and some radiobiological properties of mutants of Micrococcus radiodurans sensitive to ionizing radiations. Radiation Research 49, I97-2I 2.

Tanabe, S., Kobatake, M., Emborge, C. \& Nakano, K. (1971). Biological indicator for radiosterilization of medical supplies and comparison of the microbiological efficiencies of cobalt-60 plants. Radioisotopes (Japan) 20, 498-504.

Town, C. D., Smith, K. C. \& Kaplan, H. S. (1970). Production and repair of radiochemical damage in Escherichia coli deoxyribonucleic acid; its modification by cultural conditions and relation to survival. Journal of Bacteriology 105, I27-1 35.

Yamada, K. \& Komagata, K. (I970a). Taxonomic studies on coryneform bacteria. II. Principal amino acids in the cell wall and their taxonomic significance. Journal of General and Applied Microbiology 16, 103-113.

YAMADA, K. \& Komagata, K. (I970 b). Taxonomic studies on coryneform bacteria. III. DNA base composition of coryneform bacteria. Journal of General and Applied Microbiology r6, 21 5-224.

YamadA, K. \& Komagata, K. (1972). Taxonomic studies on coryneform bacteria. IV. Morphological, cultural, biochemical and physiological characteristics. Journal of General and Applied Microbiology 18, 399-4I6.

Yamada, Y., Inoue, G., TAhara, Y. \& Kondo, K. (1976). The menaquinone system of the coryneform and nocardioform bacteria and related organisms. Journal of General and Applied Microbiology 22, $203-214$.

Yano, K., Сho, B., Yoshinaka, T. \& Yamaguchi, H. (1975). Surveys on radiation-resistant asporogenic bacteria in natural environments. In Radiation for a Clean Environment, IAEA-SM-194/202, pp. 85-98. Vienna: International Atomic Energy Agency.

Yoshinaka, T., YANO, K. \& YAMAGUCHI, H. (I973). Isolation of a highly radioresistant bacterium, Arthrobacter radiotolerans nov.sp. Agricultural and Biological Chemistry 37, 2269-2275.

WeLCH, A. B. \& MAXCY, R. B. (I975). Characterization of radiation-resistant vegetative bacteria in beef. Applied Microbiology 30, 242-250. 